\title{
Deciduous Tree Fruit
}

\author{
F.G. Dennis, Jr., and Jerome Hull, Jr. \\ Department of Horticulture, Michigan State University, East Lansing, MI 48824-1325
}

On the occasion of the 75th anniversary of ASHS, Thompson, Faust, Martin, and Dewey (1979) individually reviewed the history of progress in temperate zone fruit physiology for the previous 75 years. The advances made during the last 25 years parallel advances in a wide range of sciences, including plant physiology, entomology, plant pathology, agricultural engineering, and computer science. New methods in instrumentation and biotechnology have changed the conduct of basic research in this area with implications that are only now being felt. Perhaps the greatest change has resulted from a greater awareness of the environmental impacts of technology, leading to a reevaluation of many of the old practices. New concepts, such as integrated pest management, organic horticulture, and environmental protection, have raised new issues that have yet to be resolved. The computers has revolutionized the collection and processing of data. The development of tissue culture for propagation of plants opened the door to its use for gene transfer, another revolutionary procedure that is currently in full flower with no end in sight. In this review we will discuss advances in tree fruit production, handling, storage, and marketing under three headings: changes in the plant, cultural practices, and postharvest procedures. Emphasis will be on applied rather than basic research.

\section{THE PLANT}

RooTsTOCKs. In the 1970s size-controlling rootstocks - primarily semi-dwarfing stocks such as M.7, M.106 and M.111 - were in wide use for apple (Malus $\times$ domestica Borkh.), but not for other fruit trees; seedlings were the main source of rootstocks for stone fruit and pear. Some growers were using full-dwarfing stocks, primarily M.9, which requires support. Research was underway testing the characteristics of other apple rootstocks, including M.27, which is even more dwarfing than M.9, as well as introductions from Canada (Ottawa series), Sweden (Alnarp), Poland, the U.S.S.R. (Budagovsky series), and France (Pajam, a more vigorous selection of M.9). A long-term cooperative project (NC-140), partially funded by the USDA, has now provided well-documented information (e.g., Autio et al., 2001) on the effects of these rootstocks on growth and yield of the scion cultivars at many locations in the United States and Canada. As might be expected, interactions among rootstock, cultivar and location are common. Cummins and Aldwinckle (1983) of the Geneva Experiment Station in New York State, motivated by the belief that the best rootstocks for North American growers would be those developed in North America, initiated a program in 1968, beginning with open-pollinated seedlings of the dwarfing rootstock M.8. They subsequently crossed other rootstock clones with hardy cultivars and screened the seedlings for dwarfing effect, ease of propagation, resistance to insects and diseases, and many other characteristics. They have released four clonal rootstocks, three of which are resistant to fireblight [caused by the bacterium Erwinia amylovora (Burr)], woolly aphid (Erisoma langerum Hausman), and phytopthora root rot. Four of these-G.11, G.16, G.30, and G.65-have been released for commercial use; others are still under test (Robinson et al., 1997). G.16 is similar in vigor to M.9, G.11 (susceptible to woolly aphid) is similar to M.26, and G.30 forms a weak graft union with some scion cultivars and is best used in trellis systems. G.65 is only moderately resistant to woolly aphid, and is very dwarfing. A replacement for G.30 is expected to be released in 2004 (Robinson et al., 1997).

Several size-controlling rootstocks for sweet cherry (Prunus avium L.) are either in use or are currently being evaluated. 'Colt', a semidwarfing stock developed in England, is popular in California. The M $\mathrm{x}$ M series of rootstocks, thought to be hybrids of mazzard ( $P$. avium L.) and mahaleb ( $P$. mahaleb L.) were selected from open-pollinated seedlings of $P$. mahaleb by Lyle A. Brooks of Daybreak Nursery in Oregon. Vigor ranges from semi-dwarfing to vigorous, only one selection (M x M 14) being dwarfing. The Gisela (Giessen) series of rootstocks developed at the Justus Liebig University in Giessen, Germany, includes
Gisela 5, 6, and 12, all of which have good potential; in addition to controlling tree size, they are precocious. Trees on Gisela rootstocks are $\approx 45 \%$ to $60 \%$ as large as those on mazzard, but must be pruned heavily to maintain fruit size. These and other rootstocks are being evaluated in a cooperative NC-140 program (Kappel et al., 1998; Perry et al., 1996). Trees on dwarfing rootstocks produce fruit much earlier than those on seedlings, but one of the problems with such stocks is that cherries tend to fruit heavily every year, and trees can become stunted by excessive cropping (Lang, 2001). In commercial trials in Washington, yields were lower but fruit size was larger on mazzard seedlings than on dwarfing stocks (Lang and Ophardt, 2000).

Quince (Cydonia oblonga L.) rootstocks can be used to dwarf pear trees where severe winter temperatures do not occur. 'Old Home' $x$ 'Farmingdale' (OHXF) crosses have also been evaluated. OH x F 33 tends to yield small fruit, and OHXF 87 and 97 are used in many pear orchards.

Because of the high cost of stoolbed production of rootstocks, experiments were conducted, beginning in the mid-1970s, to produce rootstocks via tissue culture techniques. Although successful, the cost proved excessive. Zimmerman and coworkers (see Zimmerman and Steffens, 1996) produced own-rooted trees using tissue culture and compared their performance with that of trees produced by grafting scions on rootstocks. The results indicated that own-rooted trees performed as well as those that were grafted, but were not as precocious. However, the importance of small tree size makes own-rooted trees less desirable that those propagated on size-controlling rootstocks. Future research, either by standard breeding methods or genetic engineering, could lead to scion cultivars with reduced vigor, making own-rooted trees more acceptable.

Cultivar and STRAin. Breeding programs for deciduous tree fruit are reviewed by Brown (2003); here we discuss only research on cultivar and strain evaluation. In the late 1960s, 'Delicious' was the most important apple cultivar in the United States, accounting for $\approx 30 \%$ of the market. Other cultivars of importance were McIntosh (12\%), Golden Delicious (11\%), Rome Beauty (8\%), and Jonathan (6\%). By the early 1990s, 'Delicious' accounted for over $40 \%$ of production, 'Golden Delicious' was second with 14\%, and 'Granny Smith' had replaced 'McIntosh' as third. 'Fuji' (2.6\%) and 'Gala' (2\%) were now among the top 10 cultivars. Within the last 10 years, production of 'Jonagold' has increased dramatically, largely as a result of the discovery of mutations with redder fruit, and additional new cultivars, including 'Braeburn' and 'Pink Lady', have been planted in areas with long growing seasons.

A shift in cultivars has also occurred in Europe (Ligonniere, 1997). The main cultivars grown in 1960-1980 were 'Golden Delicious', 'Red Delicious', 'Granny Smith', 'Cox's Orange Pippin', 'Belle de Boskoop', and 'Morgenduft', with notable differences between southern and northern Europe. Although 'Golden Delicious', 'Red Delicious' and 'Granny Smith' have remained popular, 'Jonagold', 'Elstar', and 'Gala' have become much more important and are replacing some of the old favorites, while 'Fuji' is being planted heavily.

Numerous 'Delicious' strains have been discovered, and commercially important strains have also been found in other cultivars. A cooperative project in the 1980s compared 28 strains of 'Delicious' on two size-controlling rootstocks-M.7 and M.111 (Dennis et al., 1996). Results varied among sites, but yield per unit trunk cross-sectional area was consistently greater for spur types than for standard strains. Within the last 25 years, redder strains of several other cultivars have replaced or are replacing less highly colored ones both in the United States and in Europe (Ligonniere, 1997).

In the 1970s, commercially acceptable spur-type strains were available for relatively few apple cultivars, 'Delicious' being an exception; 'Starkrimson' was the primary strain in commercial use. Today, spur types are available for many other cultivars; 60 or more are now recognized in 'Jonagold' and 'Elstar' (Ligonniere, 1997). Some are pil- 
lar-type strains, having very short lateral branches and upright growth habit, suggesting their use in hedgerow plantings. Nonspur scions are preferable on dwarfing stocks in some cases, as growth is too limited. Dwarf peach trees are available but they are too small for commercial use. Columnar and compact types are also available, but are not useful commercially; however, intercrosses between the columnar and standard forms (mixed types) are more spreading than the columnar trees and have potential for commercial orchards (Scorza et al., 2000).

Self-fruitful sweet cherry cultivars are being introduced to overcome problems associated with self-sterility and incompatibility (Tehrani, 1988; Tehrani and Brown, 1991). The season of ripening has been broadened considerably, and resistance to mildew and leaf spot are being introduced.

\section{CULTURAL PRACTICES}

Tree Planting. The primary method of planting fruit trees in the 1970 s was to use a tractor-mounted augur to drill the hole, then plant the tree by hand and eyeball to align the trees within and across rows. The mechanical tree planter, a larger version of a vegetable transplanter, has replaced the augur. A trench is opened by a metal shaft, and the tree is inserted in the trench. Packing wheels firm the soil around the tree's base and roots. Tree alignment across rows is less important, given that most orchards are planted as hedgerows, and herbicides, rather than cultivation, are used to control weeds in the row. Planting can be accomplished much more rapidly with the mechanical planter, and this has led to higher-density plantings, acreage expansion, and orchard removal or replacement.

Planting and training Systems. The availability of dwarfing rootstocks has led to a rapid shift in planting systems, from free-standing to many different support systems. In a cooperative experiment comparing vertical axe, slender spindle, and several other methods, the vertical axe gave the greatest yield over a 10-year period (Perry et al., 1996). In some systems two wires are used, supported by a T-trellis, and alternate trees are set at an angle in a manner resembling the Geneva double-curtain system for grapes (Vitis sp.). In Europe, very high-density systems (super spindle) use as many as 3000 trees/ha, requiring high expenditures for trees. To reduce planting costs, some growers plant sleeping eye trees (budded rootstocks) rather than finished nursery trees. Precocious, full-dwarf, central leader trees require support by stakes or trellises, as well as more attention to early pruning and bending. Numerous training systems are used, the most popular being the slender spindle and the French axe.

The Long Ashton Research Station in England introduced the concept of the meadow orchard, which generated much interest (Luckwill and Child, 1973). Apple trees propagated on M.106 rootstocks were planted in beds at densities of 30,000 to 100,000 trees/ha. Once the scion approached the desired height, the plants were sprayed with succinamic acid-2,2--dimethylhydrazide (Alar) to limit growth and stimulate flower bud formation. The trees bore fruit in the second year. Following harvest (potentially mechanical), they were cut back to $\approx 30 \mathrm{~cm}$ above the ground and the cycle was repeated, resulting in biennial cropping. The advantages were high production per unit area and mechanization of some cultural practices, like those used for row crops. Although the experiment stimulated many similar studies, the system has not been adopted commercially. Erez (1976) tested the method for peach production in Israel, where the longer growing season permitted annual cropping. Two leaders were used, and one was cut back each year. Although the results were promising, small fruit size was a problem.

Pruning. Hand pruning remains the primary method used today to control growth, renew fruiting wood, and permit better penetration of light, although mechanical pruning aids (platforms, power saws, and shears) are widely used, and mechanical top and side pruning is often done to reduce labor costs. Growers strive to reduce costs by making fewer cuts when pruning. Summer pruning is sometimes practiced to increase light penetration; Marini and Barden (1987) reviewed this practice, concluding that it should be used with caution, given that it is generally no more effective than dormant pruning for limiting shoot growth or tree size.

CONTROL OF FREEZE INJURY AND PREDICTION OF END OF REST. Freeze injury - both during dormancy and during renewal of growth in the spring - remains a serious problem in fruit growing. The high price of fuel oil, together with concerns about environmental pollution, have reduced dependence on orchard heaters to prevent freeze injury and have encouraged the use of wind machines, wherever temperature inversions are sufficient, and of sprinkler irrigation (heat of fusion is released as water freezes, warming the bud). Researchers at Utah State University introduced a model (the Utah model) to predict the end of the rest period and the beginning of bud development in the spring (Richardson et al., 1974). This was based on evidence that temperatures below $0{ }^{\circ} \mathrm{C}$ had no effect in breaking rest, temperatures between 0 and $16^{\circ} \mathrm{C}$ had positive effects, and those above $16^{\circ}$ had negative effects. Thus, both the end of rest and the time of bloom could be predicted, based on temperature records.

The Utah model is applicable in areas with cold winters but less useful in areas with warm ones, as in the subtropics. Erez et al. (1990) therefore developed a dynamic model based on the work of Fishman et al. (1987). This model assumes that, once chilling units have been accumulated, the effect cannot be negated by subsequent high temperatures. Comparison of the two models indicated that the dynamic model was the better predictor of end of rest at low latitudes (Erez et al., 1988).

The Utah team suggested that bud development could be delayed by evaporative cooling, thereby reducing the chance of freeze injury (Alfaro et al., 1974). Intermittent sprinkling of fruit trees with water whenever the temperature rose above a threshold delayed bud development; in Utah's arid climate bloom could be delayed for 2 to 3 weeks (Anderson et al., 1975). Response was less dramatic in more humid areas (Crassweller et al., 1981). Fruit set was reduced in some cases but not in others, and fruit maturation was generally delayed; however, the delay in maturity was less than the delay in bloom. Although the method was effective, few growers have used it, given the cost of installation and some side-effects such as reduced fruit set and accumulation of calcium deposits on the trees.

Bloom can also be delayed chemically. Proebsting and Mills (1973) first demonstrated that application of ethephon in the fall could delay bloom of peach (Prunus persica Batsch.) the following spring. Additional studies confirmed this, but practical application has been limited because high rates can lead to severe gummosis in stone fruit and/or permanent delay of bud opening (Dennis et al., 1976). Application of aminoethoxyvinylglycine during bud swell delayed bloom of peach and rabbiteye blueberry (Vaccinium ashei Reade) (Dekazos, 1979, 1981), but high concentrations were required.

Nutrition. Leaf and soil analysis continue to be used to assess nutrient status and need. Today, commercial companies perform the analyses once only available from universities. Computer analysis of the resulting data permits automation of recommendations and almost instant feedback to the grower. However, the problem of variation among trees and sites complicates application of this information (Sanchez et al., 1995). Several factors, including tree age and vigor, must be considered. For example, nutrient levels in vigorous trees may be lower than those in weak trees, yet the former may contain adequate nitrogen. Ideally, fertilizer should be applied on a tree-by-tree basis. This is being done with some field crops based on soil type and other factors (see Sanchez et al., 1995) but would be difficult or impossible in orchards. However, Sanchez et al. (1995) suggest methods by which greater precision in applying fertilizer might be achieved.

Overfertilization is common in orchards, given the low cost of nitrogen and the risks of light crops; thus, there is little incentive for farmers to reduce rates, resulting in low fertilizer use efficiency, leaching, and environmental pollution. Both Sanchez et al. (1995) and Weinbaum et al. (1992) discuss this problem in some detail. The pioneer work of Weinbaum et al. $(1978,1984,1987)$ with ${ }^{15} \mathrm{~N}$ as a tracer revealed that nitrogen applied to almond (Prunus dulcis L.) and prune (P. domestica L.) trees before leaf fall is stored in woody tissues and is remobilized for fruit set in the spring, whereas that applied in the winter or spring becomes available only after rapid shoot growth begins - too late to affect fruit set. This was confirmed in pear by Sanchez et al. (1990). The use of ${ }^{15} \mathrm{~N}$ has become a standard practice for evaluating fertilizer use efficiency.

ORCHARD FLOOR MANAGEMENT AND IRRIGATION. The most common method of management involves sod cover between rows and applica- 
tion of herbicides for control of weeds and grass in the tree row. Shribbs and Skroch (1986) observed greater growth of apple trees in areas kept free of vegetation, either by herbicides or cultivation, and Walker and Glenn (1988) obtained similar results with peach trees. The public's concern for environmental effects of herbicides has focused research on other methods of vegetative control; these include mulches and surface barriers to vegetation. Parker (1990) observed greater soil moisture levels beneath trees in clean cultivation and herbicide-treated areas than under complete sod. A sod of tall fescue (Festuca arundinacea Schreib) reduced soil moisture more than one of hard fescue [Festuca ovina ssp. duriuscula (L.) Koch].

Allelopathy is the inhibition of growth of one plant by toxic substances released from another (Putnam and Tang, 1986). Plants that secrete toxic compounds include canada thistle [Cersium arvense (L.) Scop.], oats (Avena sativa L.), rye (Secale cereale L.), wheat (Triticum aestivum L.), sorghum [Sorghum bicolor (L.) Moench.], quackgrass (Agropyron repens Beauv.), and yellow nutsedge (Cyperus esculentum L.) (Putnam et al., 1983). Apple and sour cherry (Prunus cerasus L.) trees grown in rye, sorghum, or wheat cover crops that were planted in the fall and killed with herbicide in the spring, had larger trunk diameters and shoot lengths than trees grown in a mowed fescue $(F$. rubra ) cover (Putnam et al., 1983).

Drip (micro) irrigation was introduced in the 1960s and 1970s and adapted for commercial use. It provided more efficient use of water and more automated irrigation. Introduction of microsprinklers has had similar effects. Even in areas with adequate rainfall, growth of young trees may benefit from irrigation. Introduction of the neutron probe provided a reliable method for measuring soil moisture. Chalmers et al. $(1981,1984)$ used restricted deficit irrigation to reduce vegetative growth of peach trees. They noted that a reduced water supply during Stage II (DW II) of fruit growth suppressed vegetative growth. Fruit growth at this time was relatively insensitive to moisture stress, and the capacity of fruit to complete for assimilates during DW III was enhanced by previous water stress.

Pest Control. Environmental concerns are important in directing research on pest control. Beginning in the 1970s, many studies have involved the effects of environmental factors, especially temperature, on the life cycles of insects and disease organisms. By using traps for insects and fungal spores, the need for, and timing of, pesticide applications can be better assessed. These integrated pest control programs and new pesticides have reduced the amount of such chemicals required to produce a crop.

Fireblight has become a major problem in dwarf apple orchards, given the susceptibility of M.7, M.9, M.26, and many of the newer cultivars, including 'Gala', 'Jonagold', and 'Braeburn'. Applications of streptomycin during bloom have become the main method of control. However, these are ineffective on shoot and rootstock infections, and the pathogen is becoming resistant. Modeling studies, using temperature and wetting time data, led to development of programs for predicting infections; an example is the MARYBLYT program (Steiner and Lightner, 1992). This and other control methods were reviewed by Aldwinckle and Beer (1979) and Aldwinckle et al. (1998). More recently, Yoder et al. (1999), and Jones (1999) reported that Apogee (prohexadione-calcium), a growth retardant, reduces susceptibility to fireblight in apple by restricting shoot growth, but streptomycin is still needed for control of blossom infection. New blight-resistant cultivars and rootstocks (see above) are essential for controlling this problem.

Plum pox, a virus disease of considerable importance in Europe (Llacer and Cambra, 1998; Roy and Smith, 1994), is currently making inroads in North America. Infested areas have been quarantined and infected trees are being eradicated.

For insect control, degree-day models facilitate timing of insecticide application to coincide with time of emergence of adults, egg-laying and hatching, larva development, etc., resulting in more effective use of pesticides. Pheromones have been isolated, identified, and synthesized for trapping and monitoring insects and disrupting their mating. Handapplied dispensers (plastic straws) filled with solutions of pheromones are twisted around twigs and are the most reliable method used to date. The solution slowly evaporates, releasing the active ingredient, which interferes with mating. Aerosol canisters (puffers), which discharge minute amounts of liquid pheromone at intervals, are also being used, thereby reducing the number of straw dispensers needed. Puffers are easy to place in the orchard (5/ha), last an entire season, and can be refilled. The aerosol can be loaded with one or several pheromones. Sprayable pheromones are promising alternatives; they can be combined with other sprays, and distribute the pheromone uniformly throughout the tree. With this technology, the pheromone is encapsulated within microscopic, polymeric capsules and is slowly released following application to the tree. However, there are concerns about their efficacy and longevity. Another method under test is spraying with kaolin clay, a common food additive, to coat the fruit with a protective layer, thereby interfering with host recognition and, thus, oviposition (Wise et al., 1999).

Insect growth regulators (IGR) including juvenile hormones, which prevent or induce insect molting and thus block reproduction, are also being used. Confirm induces premature molting in the Lepidoptera; codling moth (Cydia pomonella L.) larvae are trapped within their skins and are unable to feed (Brunner, 1988). In Europe, diflubenzuron and teflubenuron, both of which inhibit chitin synthesis, and fenoxycarb are used for this purpose (Blommers, 1994). These and other insect growth regulators control mites, codling moths, and leaf rollers; viruses are also used for codling moth.

Beneficial mites are used to control other mite species that attack the leaves and reduce yields. They are also killed by some miticides and other pesticides, but applications of such chemicals are limited in integrated programs. Scouts monitor mite and insect populations periodically and advise on the need for pesticide application.

Emphasis has shifted from integrated pest management to integrated crop management, including rodent control and application of fertilizers, herbicides, and growth regulators. Many improvements have been made in pest control equipment. Growers have shifted from air-blast equipment and dilute sprays to concentrated ( 3 to 5 times or higher) sprays. These require less water and reduce the total amount of time expended in filling tanks. Reduced spray droplet size provides more uniform coverage. Some sprayers are equipped with photocells that shut off nozzles when there is a space in the tree row, thus saving pesticide and reducing pollution. The older air-blast sprayers tended to deliver more pesticide to the bottom of the tree than to the top-a defect that was especially critical when applying growth regulators, where differences in concentration are very important. Modern sprayers with booms, masts, towers, or fans that can be rotated in various directions can deliver the pesticide to the trees more evenly.

Lyons and Byers (1983) proposed tree-row volume as a technique to determine rate of application. Tree-row volume requires that $1 \mathrm{gal}$ $(3.78 \mathrm{~L})$ of spray solution be applied uniformly to every $1425 \mathrm{ft}^{3}[40.3$ $\left.\mathrm{m}^{3}\right]$ of tree row sprayed. The shift to size-controlling rootstocks has greatly reduced the amount of pesticide used per hectare. Furthermore, training method affects rate of deposition. In a comparison of several high-density systems, Byers et al. (1989) reported a 3- to 5-fold difference in the amount of pesticide deposited.

The goal of the 1994 USDA integrated pest management (IPM) initiative was to reduce pesticide use and ensure that $75 \%$ of the planted acreage would adopt IPM methods. The results to date are, overall, pesticide use has increased $4 \%$, the use of risky pesticides has decreased $14 \%$, and IPM is now used on $71 \%$ of the total crop area (Coble, 2003).

Organic fruit production has been practiced in Europe for 2 decades. North American growers' interest in organic fruit production has been increasing, and the area of orchards treated increased 2-fold in the 1990s. The USDA's national organic standards went into effect in 2002, providing a definition of organic and detailing the methods, practices, and substances that can be used in organic production and handling. Management is a much greater factor in organic pest control programs than in traditional ones. Experiments are underway to determine how best to produce fruit while limiting pesticide use. Washington is leading the way in the United States, given its semi-arid climate, which limits damage from apple [Venturia inaequalis (Cooke) G. Wint.] and pear scab (Alway, 2001) Although scab-resistant apple cultivars (e.g., 'Liberty', 'Gold Rush') are available commercially, none has been heavily planted in the Eastern United States; furthermore, resistance tends to break down as the fungus mutates. Were acceptable cultivars available, organic production might increase rapidly (Granatstein, 
2002). Prices for organically grown apples and pears are higher than for nonorganic fruit, but the difference has declined over the past 10 years, and subsidies may be necessary to encourage continued production (Granatstein, 2002).

Current cooperative experiments involve not only pomologists, but entomologists, nematologists, plant pathologists, weed scientists, economists, and growers, as well. Organic pesticides are being compared with synthetic ones in terms of both efficacy and persistence, and groundcovers and fertilizers are being evaluated. Legumes are being tested as nitrogen sources, with or without tillage or mulch in the tree row, and groundcovers that kill the insects that feed on them are being evaluated.

Birds can do considerable damage to fruit, especially cherries and blueberries. Applicaion of high rates of methiocarb (Mesurol), a broadspectrum carbamate insecticide introduced in the 1970s that is distasteful to birds feeding on the treated fruit, was an effective bird repellent but is no longer approved for use. Sprays of methyl anthranilate (Rejexit) repel birds feeding on cherries, grapes, and blueberries; its effects are enhanced when used with traditional control methods, including bird-scaring devices such as carbide guns (exploding cannons fired with propane), firecrackers, artificial hawks, balloons with eye spots, and broadcasting of recordings of birds' distress calls.

FLOWERING. Gibberellins (GA) inhibit flowering in deciduous tree fruit. Southwick et al. (1995) and Southwick and Gloz (2000) demonstrated that application of GA reduced the need for hand thinning the following year, thus reducing costs. This has led to commercial adoption of the practice, at least in areas where winter injury to flower buds is not a serious problem.

Parker et al. (1969) showed that GA partially overcame the reduction in vigor in sour cherry induced by sour cherry yellows virus, but commercial application was limited. In a long-term study, Bukovac and Yuda (1990) and Bukovac (unpublished data) confirmed that annual applications of GA to sour cherry inhibited flowering, favored development of fruiting wood, and increased yield. Over a 9-year period in which $\mathrm{GA}_{3}$ was applied annually at 15 to $20 \mathrm{mg} \cdot \mathrm{L}^{-1}$, yield per tree averaged $50 \mathrm{~kg}$ for the control vs. $64 \mathrm{~kg}$ for the treated trees, a highly significant $28 \%$ increase. Considerable use is currently made of GA for this purpose by commercial growers.

Pollination And Fruit SeT. Growers have begun to shift to singlecultivar orchards to facilitate orchard operations. Cross-pollination is required or beneficial for all apple cultivars, and pollinizers are needed in such orchards. Much research effort was devoted to selecting crabapple cultivars most effective as pollinizers, as these could be interplanted with the cultivar of interest and pruned heavily to prevent competition. For example, Crassweller et al. (1980) compared 59 crabapple cultivars as pollinizers, considering their time of bloom and pollen quality, and recommended several for commercial use. The flower color of the pollinizer should match that of the cultivar pollinated, as individual bees tend to work flowers of one color.

The effect of cultivar differences in flower structure on bee activity were investigated by Robinson (1979), who found that flowers of some cultivars, including 'Delicious', were side-worked, rather than top-worked. Bees normally top-work to obtain nectar and transfer pollen in the process. Side-workers insert their tongues between the stamen filaments and do not pick up pollen in the process. Robinson found that 'Delicious' blossoms tend to have many spaces between the filaments, encouraging side-working, and attributed poor fruit set to this characteristic. However, subsequent work by DeGrandi-Hoffman et al. (1985) did not confirm his conclusion that side-working affects yield appreciably. They further provided evidence that pollen was transferred from bee to bee within the hive, thus lessening the need for close spacing between cultivars.

Several chemicals or mixtures thereof, including compounds that mimic insect pheromones, are available that purportedly attract bees to flowers. However, the results of orchard tests (e.g., Tew and Ferree, 2000 ) have generally been disappointing. One problem is that spray applications deposit the compounds on all of the exposed tissues rather than on blossoms alone.

Fruit growers depend primarily on honey bees (Apis mellifera $\mathrm{L}$ ) for pollination. In recent years, however, honeybee tracheal mites, Varroa jacobsoni (Oudemans) in particular, have decimated both wild and domestic honey bee populations in most parts of the world (Sammatoro et al., 2000) and other pollinators have been sought, including blue orchard bees (Osmia lignaria). These insects reportedly work at lower temperatures than do other species of bees. Bosch and Kemp (1999) obtained high yields of sweet cherry by introducing blue orchard bees in an orchard that had previously borne poor crops. However, no honey bees were used for comparison. Torchio (1985) has studied the effects of the bees on apple yields, and the species is being used on a trial basis in almond (Prunus dulcis L.) plantings in California (Traynor, 2001).

Aminoethoxyvinylglycine (AVG) inhibits ethylene synthesis and increases fruit set of apple and pearbut not stone fruit (Dennis et al. 1983; Edgerton, 1981; Greene, 1980, 1981; Williams, 1980). The responses were dramatic, but commercial development was prohibited by the high cost of producing the chemical. This compound, now produced more cheaply and marketed as Retain, is used commercially for controlling preharvest fruit drop (see below), but little or none is used for improving fruit set. Gibberellins are effective in inducing parthenocarpy in a wide range of fruit, but little use has been made of them for this purpose. The major use is on seedless grapes (Vitis vinifera L.), in which set is actually reduced but fruit size is increased. In the southern U.S., however, GAs are used to increase set in rabbiteye blueberry following freeze injury to the stigmas and styles during bloom.

FLOWER AND FRUIT THINNING. An entire issue of Plant Growth Regulation (vol. 31, nos. 1 and 2) was devoted to this subject. Historical aspects of thinning were reviewed by Dennis (2000), and several aspects of thinning of both stone and pome fruit by Fellahi and Willemsen (2000), Greene (2000), Unrath (2000) and others. Naphthaleneacetic acid (NAA) and carbaryl [1-naphthyl N-methylcarbamate (Sevin)] are standard chemicals for thinning apples. Benzyladenine (BA) was tested as a fruit thinner in the early 1990 s, resulting in the introduction of a commercial product - Accel - that also contains a small amount (1.8\%) of $\mathrm{GA}_{4+7}$. It is a weak thinner, and is being replaced by MaxCel, which contains only BA and is more effective. The product may also increase fruit size independently of its thinning effect. Computer programs (e.g., Jones et al., 2000; Williams and Wright, 1991) are available to assist growers in determining appropriate concentrations of chemicals based on weather conditions, previous tree history, and other factors.

Experiments with stone fruit, primarily peach, have yet to result in commercially acceptable thinning agents. Although ethephon is effective, response is erratic and leaf abscission is excessive. Byers et al. (2003) have reviewed recent literature on this subject.

Flower thinning (see Fellahi and Willemsen, 2000) has advantages over fruit thinning in that the earlier thinning is performed, the greater the potential effect on fruit size. However, in areas with low winter temperatures or frequent spring frosts, early thinning may be unwise. Dinitro compounds, e.g., Elgetol, used commercially in the Pacific northwest for many years, are no longer approved for use. Apple production in Washington has fluctuated since then, reflecting a distinct tendency toward biennial bearing. Williams $(1993,1994)$ and Williams et al. (1995) investigated the effects of several alternative compounds for blossom thinning; among the most effective were sulfcarbamide and pelargonic acid. However, little or no commercial use is made of these chemicals. Ammonium thiosulfate or nitrate can be used to kill flowers but is also injurious to foliage; therefore, it must be used with caution. Peach is less susceptible than apple, as the foliage is less advanced at the time of bloom.

Mechanical thinning of blossoms by hand is possible but prohibitively expensive. Blossoms can also be thinned with brushes or brooms or by machine. A commercial rope thinner (Baugher et al., 1991) is used by some peach growers. This drags heavy ropes over the tops of the trees while rotating the ropes horizontally. Follow-up hand thinning is necessary to thin the flowers in the lower part of the tree. Both clubs and mechanical tree shakers can be used for thinning peach fruit before Stage III (final swell), but not for apples, as bruising is excessive (Schroeder and Link, 1996).

Рнотоsynthesis. Several advances have been made in the study of photosynthesis and the partitioning of carbohydrates in fruit trees (see Flore and Lakso, 1989). These were facilitated by advances in instrumentation for measuring light level and both $\mathrm{CO}_{2}$ and $\mathrm{O}_{2}$ levels in air. Hand-held devices, equipped with light meters and attached to 
instruments that measure such levels, are now used both in the field and in the laboratory. These measure the concentrations of the gases entering and leaving the leaf chamber, and, from these data, together with the area of surface exposed, the rate of photosynthesis can be determined.

In addition, plastic balloons are available that completely enclose the tree and are kept inflated by pumping air into the chamber. Thus, the photosynthetic rate can be calculated for the entire tree and the effects of various factors - light, pruning level, fruiting, etc. - on photosynthesis can be determined with the help of a computer. Heinicke and Childers (1937) performed a similar experiment but measured the differences in $\mathrm{CO}_{2}$ content of the air chemically rather than electronically - a very laborious procedure!

Such whole-plant systems are useful for measuring net photosynthesis (Corelli-Grappedelli and Magnanini, 1998; Miller et al. 1996). They are preferable to single-leaf or shoot methods in that they eliminate the variations among leaves that result from differences in age and exposure to light and integrate the effects of respiration by nonphotosynthetic tissues and organs. However, they are more cumbersome than singleleaf measurements, requiring more time to set up and to move from one plant to another, thus reducing the number of observations that can be made. Such studies have indicated that the rate of photosynthesis is higher in fruiting than in nonfruiting trees (Fuji and Kennedy, 1985; Giuliani et al. 1997b) and that lightly cropped trees are better able to withstand mite infestation than are trees with normal crop loads (Francesconi et al.,1996).

ConTrol of Vegetative Growth. Reducing vegetative growth is desirable under some circumstances, especially when crop load is low and in close plantings. Summer pruning limits growth but is expensive, as hand labor is required. Root pruning (cutting of roots with a chisel or disk) can reduce shoot growth but may also reduce fruit size (Ferree, 1992; Geisler and Ferree, 1984). Several chemical growth retardants were evaluated in the 1960s and 1970s, including Alar. This chemical was widely used to reduce preharvest fruit drop and increase fruit firmness and storage life but was relatively ineffective in controlling growth at the concentrations used. Claims that it was carcinogenic led to its withdrawal from the market by the manufacturer. Paclobutrazol (Cultar) is another growth retardant whose effects are dramatic and very persistent. Although available in Europe, it has not been cleared for use in the United States. A new candidate for growth control, Apogee, is more effective than Alar and less persistent than paclobutrazol on apple but is inactive on peach (Byers and Yoder, 1999). Elfving et al. (2003) reported that application of Apogee to sweet cherry partially controlled vegetative growth but was much more effective when combined with ethephon. The combination spray also promoted flowering, ethephon being responsible for most of this effect.

Insufficient chilling is an important limitation to production of deciduous fruit in the subtropics and tropics. The standard treatments used to stimulate growth in the spring are sprays of dinitro-o-cresol (DNOC) and/or oil. Sprays of hydrogen cyanamide are also effective (e.g., Dozier et al., 1990), and a commercial formulation, Dormex, is now extensively used to force the buds of tree fruit and grapes. In selected tropical and subtropical areas, defoliation shortly after harvest induces budbreak in peach, and two crops of fruit can be produced per year (Ramirez, 1987).

COLOR DEVELOPMENT, FRUIT MATURATION, AND PREVENTION OF PREHARVEST FRUIT DROP. Color development is important in most apple cultivars. Japanese growers bag 'Fuji' apples during development to produce fruit with the color consumers prefer (Kikuchi et al., 1997). Two layers of paper are placed around fruit 4 to 6 weeks after petal fall. These bags are removed 4 to 6 weeks before harvest, and color develops thereafter. Washington growers are using similar techniques to produce 'Fuji' for export to Japan.

Chemicals are available for delaying, as well as hastening, fruit maturation; some of these chemicals also delay or hasten fruit abscission. NAA has long been used to delay preharvest fruit drop in apple, although it simultaneously stimulates ripening. Ethephon breaks down in the tissue, releasing ethylene, the naturally occurring hormone that stimulates ripening. It is used commercially on a number of fruit to hasten ripening and thereby obtain higher prices on the early market, and/or concentrate ripening and reduce the number of harvests. It is also used to facilitate mechanical harvesting of cherry and other fruit by reducing the fruit removal force. Bukovac et al. (1969) and Bukovac (1979) pioneered work on this response, leading to successful mechanical harvesting of both sour and sweet cherries for processing.

Alar also hastens and concentrates ripening in both sour (Unrath et al., 1969) and sweet cherry (Chaplin and Kenworthy, 1970), but has the opposite effect on pome fruit. As noted above, it can no longer be used commercially. ReTain (AVG) delays both ripening and preharvest drop of apple (Greene, 1996).

Proebsting (1972) and Proebsting et al. (1973) demonstrated the beneficial effects of GA in delaying maturity in sweet cherry in Washington, resulting in larger fruit, and, in some cultivars at least, better canning quality. Commercial use of GA for this purpose is now a common practice in the northwestern U.S.

Previous methods for determining optimum time of harvest have been supported by advances in instrumentation, especially gas chromatography, for detection of volatiles. Ethylene is the primary ripening hormone in climacteric fruit and can be measured either by removing gas samples from the fruit with a syringe or by measuring the gas in the head space of a container in which a sample of fruit is kept. This information, together with data on time from full bloom, temperature during the growing season, soluble solids content, flesh starch content, and other variables, is used to determine when pome fruit should be picked, no one criterion being useful by itself (Kingston, 1992). Considerable research is being focused on the mechanisms of action of ethylene and its perception by plant tissue.

FRUIT QUALITY. Efforts are being made to make the evaluation of fruit quality more objective. Improvements in gas chromatography-mass spectrometry, together with data bases available on the Web, have encouraged research in identification of fruit flavor components (see Yahia, 1994). This requires separation and identification of volatiles as well as evaluation of their sensory qualities. Guadagni et al. (1966) separated compounds in the essence of 'Delicious' apples. Three compounds had a characteristic apple aroma and were subsequently identified as ethyl 2-methylbutryate, 2-hexenal, and hexanal (Flath et al., 1997). Similar work was conducted by Panasuik et al. (1980) with essence of 'McIntosh' apples, and correlations were established between aroma intensity and both putative hexanal and 2-hexenal.

Medical research has associated consumption of fruit and vegetables with reduced susceptibility to degenerative diseases (Block et al., 1992; Steinmetz and Potter, 1996), but the effects cannot be explained by content of essential nutrients. The term phytonutrients is applied to the compounds responsible (Beecher, 1999). Many of these are phenolics, and their antioxidant properties appear to be responsible for their effects. (Kalt, 2001). Apples are one of the major sources of dietary flavanoids, including hydroxycinnamates, especially chlorogenic acid, and chalcone flavanoids (phloridzin and phloretin glycoside) (Miller, 1998). The distribution of these compounds in the fruit has been reported (Awad et al., 2000). Perhaps there is a scientific basis for the old adage "An apple a day keeps the doctor away."

HaRvesting AND HANDling. Machines for harvesting cherries, plums, and cling peaches for processing were available in the 1970s. Most of the early models shook individual limbs rather than the trunk; therefore, several attachments per tree were required to remove the fruit. Agricultural engineers, in cooperation with horticulturists, developed shaker heads that attach to the trunk and shake the entire tree, allowing more rapid harvest. Such equipment moved more quickly through the orchard and caused less damage to the tree. Early models of both limb and trunk shakers damaged the bark, but use of lubricants, together with addition of padding materials and other modifications of the shaker head, can prevent most of this damage.

Catching frames vary from roll-out models in which a canvas is pulled under the tree manually then rolled up mechanically to canvascovered frames with two halves, one on each side of the tree, that deliver fruit to a conveyor in the center, to wrap-around machines that can be operated by one person. Over-the-row harvesters similar to those used for some small fruit, including grapes, blueberries, and raspberries (Rubus sp.) have been tested on apples in the United States, but damage to the fruit was excessive. Some were used for apples for processing when labor was scarce in the 1970s, but with sufficient labor the shakers remained unused. Subsequent research by USDA 
investigators was terminated under pressure from groups concerned about displacement of labor.

Mechanically harvested sour cherries are collected and transported in tanks of water, thereby reducing bruising, and cold well water is circulated through the tanks for several hours after harvest to cool and firm the bruised fruit before processing, In contrast, plums, cling peaches, and sweet cherries used for canning are harvested dry. Sweet cherries for brining can be harvested directly into brine-filled tanks. Because fruit harvested in water cannot be weighed easily, their volume is recorded with a specially designed plunger.

Mechanical aids for hand harvest of apple and pear continue to be developed. Most of these make harvesting easier for the worker but do not reduce harvesting costs. Some experimental European machines transport the workers, the fruit being delivered to a common container.

\section{POSTHARVEST}

PACKInG. Water dumpers were introduced in the 1980s to transfer apples and pears from bulk bin to sorting table. The bins are immersed in water, and the fruit floats out before elevation to the sizer. The advent of computers, coupled with light-sensing systems, now permits the sorting - and rejection - of apple, cherry, and other fruit based on color characteristics, including both intensity and area of the fruit covered, as well as the presence of defects and misshapen fruit.

Both tray packs and plastic bags continue to be used for packing apples, but computer-aided mechanisms are now extensively used for sizing. Cups that permit the weight of each fruit to be recorded deliver a given weight of fruit, which is then packaged manually or automatically. Fruit of similar size can also be delivered for tray packs. Labeling of individual fruit of some species, including apple, pear, and peach, with paper labels indicating source and PLU number has now become a common practice.

Fruit for fresh use are commonly waxed or otherwise coated for several reasons, primarily to reduce water loss and improve sales appeal. Several commercial products are used. Polyethylene wax is used for some products, but consumers are demanding more natural products. Norway now prohibits importation of waxed fruit (Amarante and Banks, 2001), leading to research on other coatings, such as polysaccharides and proteins, and their effects on water loss and on fruit disorders such as scald, core flush, and internal breakdown.

Processing. Drying of deciduous tree fruit has been limited except for plums (prunes) and apricots, although dried apples, pears, and peaches are available in small quantities. However, the market for dried sour cherries has expanded over the past 20 years, largely because of procedures introduced by one Michigan company, which has now expanded its product line to include apples, blueberries, raspberries, strawberries (Fragaria annanasa Duchesne), cranberries (Vaccinium macrocarpon), and several tropical fruit. The current emphasis on antioxidants for prevention of cancer and other ailments has provided a boost for the marketing of concentrated sour cherry juice. Anthocyanins in the juice act as pain killers (Wang et al., 1999)

STORAGE. Controlled atmosphere (CA) storage was developed in England and introduced commercially in the United States in the 1950s, largely as a result of the work of R.M. Smock at Cornell. Several advances have since been made in CA storage of apples and pears (Dilley, 1990b). If the oxygen level falls too low, fermentation will occur. To prevent this, oxygen levels had to be relatively high. The introduction of electronic instrumentation allowed more accurate measurement of the concentration of oxygen and carbon dioxide. Oxygen concentration could now be lowered to $0.5 \%$ or $1 \%$, thereby prolonging storage life.

Catalytic converters that used propane burners were the major method of reducing oxygen levels in cCA storages in the 1970s but were unsafe, and a number of explosions occurred. Both pressure-swing adsorption and hollow-fiber membrane systems for separating oxygen and nitrogen were introduced in the mid-1980s, as described by Dilley $(1988,1990 a)$. These systems have largely replaced the catalytic converter. They provide an economical source of nitrogen, which is used to purge the room and to maintain the appropriate atmosphere during storage. Today, once a room is filled, the air is removed by flushing with nitrogen, and the CA system is thus established within 1 or $2 \mathrm{~d}$. In addition fruit can be removed for sale and the atmosphere reestablished with only a brief exposure of the fruit to normal atmospheres.

Although hypobaric (low-pressure) storage was extensively studied as a means of extending storage life, the cost of building storages capable of withstanding pressure differences of $600 \mathrm{~mm}$ of mercury (760 to $150 \mathrm{~mm}$ ) was too high for commercial application. However, containers have been developed for hypobaric shipment of numerous perishable items, including fruit, flowers, and fresh meats.

Scald is a major problem in stored apples and pears (Ingle, 2001; Wang and Dilley, 1996, 2000). Barden and Bramlage (1994), working in the eastern U.S., were able to predict the relative susceptibility of apple fruit to scald based on the accumulated time at temperatures $<10$ ${ }^{\circ} \mathrm{C}$ during the maturation period. Smock (1957) pioneered the use of diphenylamine (DPA) treatments to control storage scald of apples, and ethoxyquin (6-ethoxy-1,3-dehydro-2,2,4-trimethyl quinoline) was subsequently found to be effective (Johnson et al., 1980). The EPA recently restricted use of these chemicals; ethoxyquin can be used only on pears, and alternatives that do not require chemical treatment are being sought. The disorder can be reduced or totally prevented by several treatments, including hypobaric $(0.1$ to $0.2 \mathrm{~atm}$.) storage (Dilley, 1982); holding in very low levels $(0.5 \%$ to $1.5 \%)$ of oxygen either continuously or before storage at $1 \%$ and $3 \% \mathrm{O}$, respectively (Lau, 1998; Little and Peggie, 1987); exposure to ethanol vapors before storage (Scott et al., 1995; Wang and Dilley, 1996); and inclusion of antioxidants as components of sucrose-ester coatings (Bauchot et al., 1995; Little and Barrand, 1989).

Modified atmosphere packaging (MAP) has been extensively studied (reviewed by Beaudry, 2000). Ideally, differentially permeable plastic containers permit carbon dioxide to escape and oxygen to enter at rates that reduce respiration but do not lead to anaerobiosis and fermentation. Studies of MAP have included computer modeling of the effects of temperature and both composition and thickness of plastic films on respiration and on diffusion of oxygen and carbon dioxide (Cameron et al., 1989). Films whose properties change with temperature have also been evaluated. MAP is currently used for some vegetables, including lettuce (Lactuca sativa L.) (Smyth et al., 1998), but several problems have prevented its use for fruit. One is that high humidity favors the growth of mold, and another is that high rates of respiration make precise adjustment of permeability difficult, especially when the package is exposed to major changes in temperature, as when moved from a refrigerated room to the sales room.

Much progress has been made in elucidating the biosynthesis of ethylene since 1-aminocylopropane-1-carboxylic acid (ACC) was discovered as its precursor (Adams and Yang, 1979). Several compounds have been introduced that inhibit ethylene synthesis. The effects of 1-methylcyclopropene (1-MCP) gas in inhibiting ethylene action and thereby prolonging storage life of plant organs were reported by Serek et al. (1995). At concentrations as low as $1 \mathrm{mg} \cdot \mathrm{L}^{-1}$ the chemical inhibits ethylene action by binding to ethylene receptors in the tissue, thus slowing loss of firmness. It also delays the increase in respiration rate that typically occurs as apples ripen. Treated apples can be stored for 4 to 5 weeks at room temperature without ripening (Beaudry, 1999; Fan et al., 1999). MCP also reduces the incidence of storage scald and bitter pit. MCP is generated by adding water to a powder preparation. The treated fruit become insensitive to ethylene, and ethylene production is inhibited. The commercial product, StayFresh, is being used on apples and clearance for use on other fruit is expected. Because $1-\mathrm{MCP}$ is so effective, treatments to induce ripening may be required after removal from storage.

Fungi often attack fruit during storage. Janisiewicz and Korsten (2002) reviewed the use of nonpathogenic fungi to reduce such losses. Treatment with BioSave, a saprophytic strain of Pseudomas syringae, is being used commercially to compete with blue and gray mold of pear and apple, thereby reducing losses to these fungi. Aspire, a similar preparation containing spores of Candida oleophila, together with dilute solutions of the fungicide thiabendazole, can reduce losses in citrus.

MARKeting. Marketing remains a major challenge for fruit growers as world production increases Many countries are overproducing fruit, and the United States is currently importing large quantities of apple juice from China and Argentina. Competition has allowed the 
customer to be very selective; the 57-mm-diameter apple is no longer marketable for anything but juice. Producers near a population center can market produce directly to the consumer, but most growers must rely on wholesale markets. Unfortunately for the grower, such markets are highly centralized and buy a high percentage of the fruit produced in the United States. To operate successfully, growers and/or packing houses must pack under the same label to offer larger volume to retailers. Another problem is foreign competition. While the North American Free Trade Agreement gave an advantage to U.S. growers in the Mexican apple market, strawberry growers have lost market share to Mexico. Competition from other apple-producing countries, especially New Zealand, Chile, Argentina, and China, has been strong. This has led to more consolidation among fruit packers as well as marketing agreements between potential rivals, such as the sale of Chilean blueberries by U.S. blueberry growers in the off-season. Currently, imports of apple juice from China have depressed the price of this product in the United States, and there is concern that imports of fresh fruit may soon follow, given the huge expansion of Chinese plantings.

The 1994 North American Free Trade Agreement between the United States, Canada, and Mexico calls for complete elimination of agricultural tariffs by January of 2008 (Glickman, 2003). The United States has increased sales of meat and livestock to Mexico and imported more fresh fruit and products made from them. There have been attempts to negotiate free trade agreements with other areas of the world. There is skepticism over free, yet unequal, trade. Free trade cannot work miracles, but much is expected as nations work toward a level playing field where all countries compete on an equal basis.

Following the trend in marketing salad greens and cut vegetables, companies have begun to market fresh-cut fruit. The major problem is tissue browning, but this can be controlled by treating the cut surfaces with antioxidants. Calcium-based coatings keep cut sections of apple, pear, and other lightly processed produce fresh for up to 4 weeks in appropriate packaging. White-fleshed cultivars of apple appear to be best for fresh-sliced fruit.

\section{BIOTECHNOLOGY}

Many of the techniques currently included in the term biotechnology, including advanced aspects of tissue culture, gene transfer, somatic hybridization, cell fusion, genomics, etc., were in their infancy in 1975. Practical application of molecular biology was only a dream in 1975; today it is a reality - and the cause of considerable controversy. While some proclaim that it will be the solution to the world food shortage, as well as a means of reducing or eliminating the need for pesticides, others denounce it as unnatural and dangerous to both the ecological balance and human health. Regardless of public perception, biotechnologists are making rapid progress in obtaining new information and improving plant materials.

Gene transfer straddles the line between physiology and plant breeding and genetics. Genetics includes both genomics - the elucidation of where genes occur in the genome - and breeding - making crosses to learn more about the genes and to enhance the economic value of plants. Molecular biology has been a boon in both areas, although the perceived dangers have thus far limited economic returns.

Research in gene transfer is thriving, and microarray technology, DNA mapping, and gene and promoter isolation have permitted many foreign genes to be transferred to fruit plants (see Khachatourians et al., 2002). Progress is being made in apple (Dandekar, 2002; Korban and Chen, 2002), pear (Chevreau and Skirvin, 2002), and stone fruit (Scorza and Hammerschlag, 2002). In apple, gene transfer has resulted in improvements in resistance to insects and diseases, including fireblight, and in rooting of cuttings, overcoming self-incompatibility, reducing browning of cut fruit, and prolonging storage life by inhibiting ethylene biosynthesis (Aldwinckle and Norelli, 2000). However, none of the genotypes produced has yet been released for commercial use.

Advances continue to be made in tissue culture, an essential component of molecular biology. Tissues of many woody plants, including tree fruit, were once considered difficult to culture in vitro. Many of the problems have now been overcome and tissue culture in used routinely in molecular biology as well as for propagation of normal genotypes. Although rootstocks can be propagated using tissue culture, the method has not been economical for genotypes that can be propagated readily by traditional means.

\section{THE FUTURE}

Predicting the future is always risky, but we'll crawl out on a (fruit tree) limb in an attempt to foresee what might be expected in the next 25 years. There are high hopes for genetic engineering in many fields, including this one, despite a crowd of critics. Assuming that proponents can convince these critics that gene transfer is safe and genetic engineers can work in concert with geneticists and breeders, insect and disease resistance can be incorporated into both old and new cultivars and rootstocks, further reducing the need for pesticides. This will be accompanied by more environmentally sound methods of control using more specific chemicals, such as pheromones, for a broader range of insects. The use of precocious dwarfing rootstocks will allow rapid changes in production to meet changes in consumer preferences. We may see the day when orchards will be cropped only 10 years before changing to another cultivar. Advances in our knowledge of the genetics of dwarfing and the physiology of rooting may provide dwarf cultivars that can be propagated by cuttings, eliminating rootstocks altogether for normal conditions.

Cultural practices are changing rapidly and will continue to change, from how trees are planted, trained, and pruned to how they are sprayed and harvested. The trend will continue toward dwarf trees of apple and sweet cherry, as well as trees that are better conformed for capturing sunlight. Machine harvest of apple, pear, and freestone peaches could become a reality, although research in this area was curtailed by the USDA's decision to end its program. An elixir that can be sprayed on trees to reduce freeze injury remains but a dream, but may one day be available. Herbicides will continue to become more environmentally friendly by increasing both activity and rate of breakdown - or will be eliminated entirely by the use of organic methods. Growth regulators will continue to be found for specific purposes; some possibilities are preventing biennial bearing, improving flower and fruit thinning, stimulating photosynthesis, controlling vegetative and fruit growth, hastening or delaying fruit ripening, and improving color, shape, and size.

In marketing, fresh-cut fruit may increase sales of some fruit. If MAP can be perfected, this, too, would improve the grower's position; experimental results to date, however, have been disappointing. Amajor problem facing farmers of all commodities is overproduction - or poor distribution. Globalization has changed the playing field and made growers compete with producers who live on the other side of the world. We see no immediate solution to this problem. The creation of niche markets will affect only a small proportion of the world's farmers. International marketing agreements may be a partial solution; American blueberry growers, for example, have formed a partnership with growers in Chile, allowing sale of this fruit in U.S. stores in both summer and winter. This would not be useful with apples, however, as they can now be stored year-round.

\section{Literature Cited}

Adams, D.O. and S.-F. Yang. 1979. Ethylene biosynthesis: Identification of 1aminocyclopropane-1-carboxylic acid as an intermediate in the conversion of methionine to ethylene. Proc. Natl. Acad. Sci. USA 76:170-174.

Aldwinckle, H.S. and S.H. Beer. 1979. Fireblight and its control. Hort. Rev. $1: 423-474$.

Aldwinckle, H. and J. Norelli. 2000. Improvement of apple varieties and rootstocks by biotechnology. Compact Fruit Tree 33(2):51-52.

Aldwinckle, H., J. Norelli and M. T. Momol, 1998. Fire blight: The search for better control. Compact Fruit Tree 4:98-100.

Alfaro, J.F., E.E. Griffin, J. Keller, G.R. Hanson, J.L. Anderson, G.L. Ashcroft, and E.A. Richardson. 1974. Preventative freeze protection by preseason sprinkling to delay bud development. Trans. Amer. Soc. Agr. Eng. 17: 1025-1028.

Alway, T. 2001. The Wenatchee Valley Pear IPM Project: 1999-2001. Lessons from soft pest management programs. TC Alway Consulting, Peshastin, Wash. Http://organic.tfrec.wsu.edu/OrganicIFP/PestManagement/ WVPP2001.pdf

Amarante, C. and N.H. Barber. 2001 Postharvest physiology and quality of coated fruit and vegetables. Hort. Rev. 26:161-238.

Anderson, J.L., G.L. Ashcroft, E.A. Richardson, J.F. Alfaro, R.E. Griffen, G.R. 
Hanson, and J. Kellar. 1975. Effects of evaporative cooling on temperature and development of apple buds. J. Amer. Soc. Hort. Sci. 100:229-231.

Autio, W.R., J.L. Anderson, J.A. Barden, G.R. Brown, R.M. Crassweller, P.A. Domoto, A. Erb, D.C. Ferree, A. Gaus, P.M. Hirst, C.A. Mullins, and J.R. Schupp. 2001. Performance of 'Golden Delicious', 'Jonagold', 'Empire', and 'Rome Beauty' apple trees on five rootstocks over ten years in the 1990 NC-140 cultivar/rootstock trial. J. Amer. Pomol. Soc. 55:131-137.

Awad, M.A., A. de Jager, and M. van Westing. 2000. Flavanoids and chlorogenic acid in apple fruit: Characterization of variation. Scientia Hort. 83 249-263.

Barden, C.I. and W.J. Bramlage, 1994. Separating the effects of low temperature, ripening and light on loss of scald susceptibility in apples before harvest. J. Amer. Soc. Hort. Sci. 199:54-58.

Bauchot, A.D., P. John, Y. Soria, and J. Recasens. 1995. Sucrose ester-based coatings formulated with food-compatible antioxidants in the prevention of superficial scald in stored apples. J. Amer. Soc. Hort. Sci. 120:491-496.

Baugher, T.A., K.C. Elliott, D.W. Leach, B.D. Horton, and S.S. Miller. 1991. Improved methods of mechanically thinning peaches at full bloom. J. Amer Soc. Hort. Sci. 116:766-769.

Beaudry. R.M. 1999. Long-term storage of apple using a new ethylene action inhibitor 1-MCP. Proc. Mich. State Hort. Soc. 129:244-247.

Beaudry, R.M. 2000. Responses of horticultural commodities to low oxygen: Limits to the expanded use of modified atmosphere packaging. HortTechnology 10:491-500.

Beecher, G.R. 1999. Phytonutrients' role in metabolism: Effects on resistance to degenerative processes. Nutr. Rev. 52:S3-S6.

Block, G., B. Patterson, and A. Subar. 1992. Fruit, vegetables and cancer prevention: A review of epidemiological evidence. Nutr. Cancer 18:1-29.

Blommers, L.M.M. 1994. Integrated pest management in European apple orchards. Annu. Rev. Entomol. 39:213-241.

Bosch, J. and W.P. Kemp. 1999. Exceptional cherry production in an orchard pollinated with blue orchard bees. Bee World 80:163-173

Brown, S.K. 2003. Breeding deciduous tree fruit. HortScience (in press).

Brunner, J.F. 1988. Pest management-Novel chemicals and biological control. Compact Fruit Tree 31(3):86-88

Bukovac, M.J. 1979. Machine harvest of sweet cherries: Effect of ethephon on fruit removal and quality of the processed fruit. J. Amer. Soc. Hort. Sci. 104:289-294.

Bukovac, M.J. and E. Yuda. 1990. Gibberellin increases cropping efficiency in sour cherry (Prunus cerasus L.), p. 350-360. In: N. Takahashi, B.O. Phinney, and J. MacMillan (eds.). Gibberellins. Springer-Verlag, New York.

Bukovac, M.J., F. Zucconi, R.P. Larsen, and C.D. Kesner. 1969. Chemical promotion of fruit abscission in cherries and plums with special reference to 2-chloroethyl phosphonic acid. J. Amer. Soc. Hort. Sci. 94:226-230.

Byers, R.E., G. Costa, and G. Vizotto. 2003. Flower and fruit thinning of peach and other Prunus. Hort. Rev. 28:351-392.

Byers, R.E., K.D. Hickey, and C.H. Hill. 1972. Base gallonage per acre. Va. Fruit 60(6):19-23

Byers, R.E., H.W. Hogmire, D.C. Ferree, F.R. Hall, and S.T. Donahue. 1989. Spray chemical deposits in high density and trellis apple orchards. HortScience 24:918-920.

Byers, R.E. and K.S. Yoder. 1999. Prohexadione-calcium inhibits apple, but not peach, tree growth, but has little effect on apple fruit thinning or quality. HortScience 34:1205-1209.

Cameron,. A.C., W. Boylan-Pett, and J. Lee. 1989. Design of modified atmosphere packaging systems. Modelling oxygen concentrations within sealed packages of tomato fruit. J. Food Sci. 54:1413-1416, 1421

Chalmers, D.J.,P.D. Mitchell, and P.H. Jerie. 1984. Physiology of growth contro of peach and pear trees using reduced irrigation. Acta Hort. 146:143-149.

Chalmers, D.J., P.D. Mitchell, and L. van Heek. 1981. Control of peach tree growth and productivity by regulated water supply, tree density, and summer pruning. J. Amer. Soc. Hort. Sci. 106:307-312.

Chaplin, M.H. and A.L. Kenworthy. 1970. The influence of succinamic acid 2,2-dimethyl hydrazide on the ripening of 'Windsor' sweet cherry. J. Amer. Soc. Hort. Sci. 95:532-536,

Chevreau, E. and R.M. Skirvin. 2000. Pear, p. 263-276. In: F.A. Hammerschlag and R.E. Litz (eds.). Biotechnology of Perennial Fruit Crops. CAB Intl., Wallingford, Oxon, U.K.

Coble, H. 2003. IPM roadmap update. Crop Decisions 45(2):12.

Corelli-Grappedelli, L. and E. Magnanini. 1998. A whole-tree system for gas exchange studies. HortScience 28:41-45.

Crassweller, R.M., D.C. Ferree, and L.P. Nichols. 1980. Flowering crab apples as potential pollinizers for commercial apple cultivars. J. Amer. Soc. Hort. Sci. 105:475-477.

Crassweller, R.M., D.C. Ferree, and E.J. Stang. 1981. Effects of overtree misting for bloom delay on pollination, fruit set, and mineral element concentration of 'Golden Delicious' apple tree. J. Amer. Soc. Hort. Sci. 103:53-56.

Cummins, J.N. and H. Aldwinckle. 1983. Breeding apple rootstocks. Plant
Breeding Rev. 1:296-394.

Dandekar, A.M. 2002. Introduction and expression of transgenes in apples, p. 327-344. In: G.G. Khachatourians, A. McHughen R. Scorza, W.-K. Nip, and Y.H. Hui (eds.). Transgenic Plants and Crops. Marcel Dekker, New York.

DeGrandi-Hoffman, G., R. Hoopingarner, and K.K. Baker. 1985. The influence of honey bee "sideworking" behavior on cross-pollination and fruit set in apples. HortScience 20:397-399.

Dekazos, E.D. 1979. Effects of aminoethoxyvinylglycine (AVG) on bloom delay, fruit maturity and quality of 'Tifblue' and 'Woodard' rabbiteye blueberries. Proc. Florida State Hort. Soc. 92:248-252.

Dekazos, E.D. 1981. Effect of aminoethoxyvinylglycine on bloom delay, fruit maturity, and quality of 'Loring' and "Rio Oso Gem' peaches. HortScience 16:520-522

Dennis, Jr., F.G. 1976. Trials of ethephon and other growth regulators for delaying bloom in tree fruit. J. Amer. Soc. Hort. Sci. 101:241-245.

Dennis, Jr., F.G. 2000. The history of fruit thinning. Plant Growth Regulat. $31: 1-16$.

Dennis, Jr., F.G., D.D. Archbold, and C.O. Vecino. 1983. Effects of inhibitors of ethylene synthesis or action, $\mathrm{GA}_{4+7}$, and $\mathrm{BA}$ on fruit set of apple, sour cherry, and plum. J. Amer. Soc. Hort. Sci. 109:570-573.

Dennis, Jr., F.G., J.G. Masabni, and D.O. Ketchie. 1996. Evaluating twentyeight strains of 'Delicious' apple in Michigan. J. Amer. Soc. Hort. Sci. 12: 988-995.

Dewey, D.H. 1979. Three remarkable generations of postharvest horticulture. HortScience 14:342-344.

Dilley, D.R. 1982. Principles and effects of hypobaric storage of fruit and vegetables. Trans. Amer. Soc. Heating, Refrigeration and Air Conditioning Eng. 88:1461-1478.

Dilley, D.R. 1988. CA storage equipment for atmosphere generation and carbon dioxide removal. Great Lakes Fruit Growers News, April.

Dilley, D.R. 1990a. Application of air separator technology for the control of superficial scald of apples not treated with scald inhibiting chemicals, $p$. 656. In: Proc. $23^{\text {rd }}$ Intl. Hort. Congress, Florence, Italy.

Dilley, D.R. 1990b. Historical aspects and perspectives of controlled atmosphere storage, p. 187-196. In: M. Calderon and R. Barkai-Golan (eds.). Food preservation by modified atmospheres. CRC Press, Boca Raton, Fla.

Dozier, Jr., W.A., A.A. Powell, A.W. Caylor, N.R. McDaniel, E.I. Carden, and J.A. McGuire. 1990. Hydrogen cyanamide induces bud break of peaches and nectarines following inadequate chilling. HortScience 25:1573-1575.

Edgerton, L.J. 1981. Some effects of aminoethoxyvinylglycine, 6-benzylamino purine and gibberellins on fruit set and vegetative growth of apple. Acta Hort. 120:125-130.

Elfing, D.C., G.A. Lang, and D.B. Visser. 2003. Prohexadione-Ca and ethephon reduce shoot growth and increase flowering in young, vigorous sweet cherry trees. HortScience 38:293-298.

Erez, A. 1976. Meadow orchard for the peach. Scientia Hort. 5:43-48.

Erez, A., S. Fishman, G.C. Linsley-Noakes, and P. Allen. 1990. The dynamic model for rest completion in peach buds. Acta Hort. 276:165-174.

Erez, A., Z. Gat, and G.A. Couvillon. 1988. Evaluation of winter climate for breaking bud rest using the dynamic model. Acta Hort. 232:76-89.

Fan, X, S.M. Blankenship, and J.P. Mattheis. 1999. 1-methylcyclopropene inhibits apple ripening. J. Amer.Soc. Hort. Sci.124:690-695.

Faust, M. 1979. Evolution of fruit nutrition during the $20^{\text {th }}$ century. HortScience $14: 321-325$.

Fellahi, E. and K. Willemsen. 2000. Blossom thinning of pome and stone fruit. HortScience 37:474-477.

Ferree, D.A. 1992. Time of root pruning influences vegetative growth, fruit size, biennial bearing and yield of 'Jonathan' apple. J. Amer. Soc. Hort. Sci. 117:198-202.

Fishman, S., A. Erez, and G.A. Couvillon. 1987. The temperature dependence of dormancy breaking in plants: Mathematical analysis of a two-step model involving a cooperative transition. J. Theor. Biol. 124:471-483.

Flath, R.A., D.R. Black, D.G. Guadagni, W.H. McFadden, and T.H. Schultz. 1967. Identification and organoleptic evaluation of compounds in Delicious apple essence. J. Agr. Food Chem. 15:29-35.

Flore, J.A. and A.N. Lakso. 1989. Environmental and physiological regulation of photosynthesis in fruit crops. Hort. Rev. 11:111-157.

Francesconi, A.H.D., A.N. Lakso, J.P. Nyrop, J. Barnard, and S.S. Denning. 1996. Carbon balance as a physiological basis for the interactions of European red mite and crop load on 'Starkrimson Delicious' apple trees. J. Amer. Soc. Hort. Sci. 121:959-966.

Fuji, J.A. and R.A. Kennedy. 1985. Seasonal changes in the photosynthetic rate in apple trees. A comparison between fruiting and non-fruiting trees. Plant Physiol. 78:519-524.

Geisler, D. and D.C. Ferree. 1984. Response of plants to root pruning. Hort. Rev. 6:155-188

Giuliani, R., F. Nerozzi, F. Magnanni, and L. Corelli-Grappadelli. 1997. Influence of environmental and plant factors on canopy photosynthesis and 
transpiration of apple trees. Tree Physiol. 17:637-645.

Glickman, D. 2003. Skepticism over free, yet unequal trade. Crop Decisions 45(2):23.

Granatstein, D. 2002. North American trends for organic tree fruit production. Compact Fruit Tree 35:83-87.

Greene, D.W. 1980. Effect of silver nitrate, aminoethoxyvinylglycine, and gibberellins $\mathrm{A}_{4+7}$ plus 6-benzylamino purine on fruit set and development of 'Delicious' apples. J. Amer. Soc. Hort. Sci. 105:717-720.

Greene, D.W. 1981. Vegetative, fruit set and fruit responses following aminoethoxyvinylglycine (AVG) application on Delicious apples. Acta. Hort. 120:251.

Greene, D.W. 1996. Ethylene-based preharvest growth regulators, p. 149-159. In: K. Maib (ed.). Tree fruit physiology: Growth and development. Good Fruit Grower, Yakima, Wash.

Greene, D.W. 2000. Chemicals, timing, and environmental, factors involved in thinner efficacy on apple. HortScience 37:477-481.

Guadagni, D.G., S. Okamo, R.G. Buttery, and H.K. Burr. 1966. Correlation of sensory and gas liquid chromatographic measurements of apple volatiles. Food Technol. 20:518-521.

Heinicke, A.J. and N.F. Childers. 1937. The daily rate of photosynthesis during the growing season of 1935, of a young apple tree of bearing age. Memoir 201, Cornell Agr. Expt. Sta., Ithaca, N.Y.

Ingle, M. 2001. Physiology and biochemistry of superficial scald of apples and pears. Hort. Rev. 27:227-267.

Johnson, D.S., J.G. Allen, and T.M. Warman. 1980. Postharvest application of diphenylamine and ethoxyquin for the control of superficial scald on 'Bramley's Seedling' apples. J. Sci. Food Agr. 31:1189-1194.

Jones, A.L. 1999. Michigan's research progress in controlling fire blight. Proc. Mich. State Hort. Soc. 129:48-52.

Jones, K.M., S.A. Bounds, M.J. Oakford, and P. Gillard. 2000. Modelling thinning of pome fruit. Plant Growth Regulat. 31:75-84.

Kalt S. 2001. Health functional phytochemicals of fruit. Hort. Rev. 27: 269-315.

Kappel, F., G. Lang, R. Perry, and R. Andersen. 1998. A new NC-140 regional cherry rootstock trial for 1998. Acta Hort. 468(1):241-247.

Khachatourians, G. G., A. McHughen, R. Scorza, W.-K. Nip, and Y. H. Hui. 2002. Transgenic plant and crops. Marcel Dekker, New York.

Kikuchi, T., O. Arakawa, and R.N. Norton. 1997. Improving skin color of 'Fuji' apple in Japan. Fruit Var. J. 51:71-75.

Kingston, C.M. 1992. Maturity indices for apple and pear. Hort. Rev. 13: 407-432.

Korban, S.S. and H. Chen. 2000. Apple, p. 203-227. In: F.A. Hammerschlag and R.E. Litz (eds.). Biotechnology of perennial fruit crops. CAB Intl., Wallingford, Oxon, U.K

Lang, G.A. 2001. Intensive sweet cherry orchard systems - rootstocks, vigor, precocity, productivity and management. Compact Fruit Tree 34(1):23-26.

Lang, G.A. and D.R. Ophardt. 2000. Intensive crop management in sweet cherries. Acta Hort. 514:227-234.

Lau, O.L. 1998. Effect of growing season, harvest maturity, waxing, low $\mathrm{O}_{2}$, and elevated $\mathrm{CO}_{2}$ on flesh browning disorders in 'Braeburn' apples. Postharvest Biol. Technol. 14:131-141

Ligonniere, G. 1997. New European apple varieties. Compact Fruit Tree 30: 58-60.

Little, C.R. and L. Barrand. 1989. Seasonal orchard and storage conditions affecting storage scald in pome fruit, p. 177-184. In: Proc. $5^{\text {th }}$ Intl. Controlled Atmosphere Res. Conf. vol 1. Pome Fruit. Wenatchee, Wash.

Little, C.R. and I.A. Peggie. 1987. Storage injury of pome fruit caused by stress levels of $\mathrm{O}_{2}, \mathrm{CO}_{2}$, temperature and ethylene. HortScience 22:783-790.

Llacer, G. and M. Cambra. 1998. Thirteen years of sharka disease in Valencia, Spain. Acta Hort. 472:379-384.

Luckwill, L.C. and R.D. Child. 1973. The meadow orchard-A new concept of apple production based on growth regulators. Acta Hort. 34:213-220.

Lyons, C.G. and R.E. Byers. 1988. Tree row volume-An accurate means of determining rate per acre. Amer. Fruit Grower, February.

Marini, R.P. and J.A. Barden. 1987. Summer pruning of apple and peach trees. Hort. Rev. 9:351-375.

Martin, G.C. 1979. Growth regulators in pomology: The end of the beginning. HortScience 14:326-328.

Miller, D.P., G.S. Howell, and J.A. Flore. 1996. A whole-plant, gas-exchange system for measuring net photosynthesis of potted woody plants. HortScience 31:944-946

Miller, N. 1998. Flavonoids and phenylpropanoids as contributors in the antioxidant activity of fruit juices, p. 387-403. In: C.A. Rice-Evans and L. Packer (eds.). Flavonoids in health and disease. Marcel Dekker, New York, Basel.

Panasiuk, O., F.B. Talley, and G.M. Sapers. 1980. Correlation between aroma and volatile composition of McIntosh apples. J. Food Sci. 45:989-991.

Parker, K.G., L.J. Edgerton, and K.D. Hickey. 1969. Gibberellin treatment for yellows-infected sour cherry trees. Farm Res. 29(4):8-9.

Parker, M.L. 1990. The response of fruit trees to orchard floor management PhD diss., Mich. State Univ., E. Lansing, Mich.

Perry, R., G. Lang, R. Andersen, L. Anderson, A. Azarenko, T. Facteau, D. Ferree, A. Gaus, F. Kappel, F. Morrison, C. Rom, T. Roper, S. Southwick, G. Tehrani, and C. Walsh. 1996. Performance of the NC-140 cherry rootstock trials in North America. Compact Fruit Tree 29:37-56.

Proebsting, Jr., E.L. 1972. Chemical sprays to extend sweet cherry harvest. Washington State Univ. Ext. Mutilith 3520.

Proebsting, Jr., E.L., G. H. Carter, and H. H. Mills. 1973. Quality improvemen in canned 'Rainier' cherries (P. avium L.) with gibberellic acid. J. Amer Soc. Hort. Sci. 98:334-336.

Proebsting, Jr., E.L. and H.H. Mills. 1973. Bloom delay and frost survival in ethephon-treated sweet cherry. HortScience 8:46-47.

Putnam, A.R., J. DeFrank, and J.P. Barnes. 1983. Exploitation of allelopathy for weed control in annual and perennial cropping systems. J. Chem. Ecol. 9:1001-1010

Putnam, A.R. and C.S. Tang. 1986. The science of allelopathy. Wiley, New York.

Ramirez M. 1987. Peach production in Venezuela. Acta Hort. 199:26.

Richardson, E.A., S.D. Seeley, and D.R. Walker. 1974. A model for estimating the completion of rest of 'Redhaven' and 'Elberta' peach trees. HortScience $9 \cdot 331-332$

Robinson, T.L., J.N. Cummins, S.A. Hoying, and W. Smith. 1997. Performance of the new Cornell-Geneva apple rootstocks. Compact Fruit Tree 30:1-5.

Robinson, W. S. 1979. Effect of apple cultivar on foraging behavior and pollen transfer by honey bees. J. Amer. Soc. Hort. Sci. 104:596-598.

Roy, A.S. and I.M. Smith. 1994. Plum pox situation in Europe. Europ. and Mediterr. Plant Prot. Org. Bul. 24:515-524

Sanchez, E.E., H. Khemira, D. Sugar, and T.L. Righetti. 1995. Nitrogen management in orchards, p. 327-380. In: P.E. Bacon (ed.). Nitrogen fertilization in the environment. Marcel Dekker, New York.

Sanchez, E.E., T.I. Righetti, D. Sugar, and P.B. Lombard. 1990. Seasonal differences, soil texture and uptake of newly absorbed nitrogen in field-grown pear trees. J. Hort. Sci. 66:479-486.

Schribbs, J.M. and W.A. Skrotch. 1986. Influence of 12 ground cover system on young 'Smoothie Golden Delicious' apple trees. I. Growth. J. Amer. Soc. Hort. Sci. 111:525-528.

Schroeder, M. and H. Link. 1996. Zum Einsatzzeitpunkt einer Ausdunnungmaschine. Schweiz. Z. Obst-Weinbau 132:23,63. (CAB Abstr. 1996-4/96)

Scorza, R., D. Bass, A. Dima, and M. Rizzo. 2000. Developing new peach tree growth habits for higher density plantings. Compact Fruit Tree 33(1): $19-21$.

Scorza, R. and F.A. Hammerschlag. 2000. Stone fruit, p. 277-301. In: F.A Hammerschlag and R.E. Litz (eds.). Biotechnology of perennial fruit crops. CAB Intl., Wallingford, Oxon, U.K.

Scott, K.J., C.M. C. Yuen, and F. Ghahramani. 1995. Ethanol vapour-A new anti-scald treatment for apples. Postharvest Biol. Technol. 6:201-208.

Serek, M., E.C. Sisler, and M.S. Reid. 1995. 1-Methylcyclopropene, a nove gaseous inhibitor of ethylene action, improves the life of fruit, cut flowers and potted plants. Acta Hort. 394:337-345.

Smock, R.M. 1957. A comparison of treatments for control of the apple scald disease. Proc. Amer. Soc. Hort. Sci. 69:91-100.

Smyth, A.B., J. Song, and A.C. Cameron. 1998. Modified atmosphere packaged cut iceberg lettuce: Effect of temperature and $\mathrm{O}_{2}$ partial pressure on respiration and quality. J. Agr. Food Chem. 46:4556-4562.

Southwick, S.M. and K. Gloz. 2000. Reducing flowering with gibberellins to increase fruit size in stone fruit trees: Applications and implications in fruit production. HortTechnology 10:744-751.

Southwick, S.M., K.G. Weis, J.T. Yaeger, and H. Zhou. 1995. Controlling cropping in 'Loadel' cling peach using gibberellin. Effects on flower density, fruit distribution, fruit firmness, fruit thinning, and yield. J. Amer. Soc. Hort. Sci. 120:1087-1095.

Steiner, P.W. and G. Lightner. 1992. MARYBLYT: A predictive program for forecasting fireblight disease in apple and pear. Vers. 4.0 of a copyrighted computer program, College Park, Md. (Cited by Sutton, 1996).

Steinmetz, K.A. and J.D. Potter. 1996. Vegetables, fruit, and cancer prevention A review. J. Amer. Diet. Assn. 96:1027-1039.

Sutton, T.B. 1996. Changing options for the control of deciduous fruit tree diseases. Annu. Rev. Phytopathol. 34:527-547

Tehrani, G. 1988. Self-fertility: A new dimension in sweet cherry breeding. Highlights Agr. Res. Ontario 11(2):1-4.

Tehrani, G. and S.K. Brown. 1991. Self-incompatibility and self-fertility in sweet cherry. Plant Breeding Rev. 9:367-385.

Tew, J.E. and D.C. Ferree. 2000. Orchard evaluation of three commercial honey bee attractants for pollination and fruit set in apple. Annu. Rpt. Mich. State Hort. Soc. 130:148-151.

Thompson, A.H. 1979. Some significant mileposts in growth and development 
in pomology. HortScience 14:318-321.

Torchio, P.F. 1985. Field experiments with the pollinator species, Osmia lig naria propinqua Cresson in apple orchards. V. (1979-1980), methods of introducing bees, nesting success, seed counts, fruit yields. (Hymenoptera: Megachilidai.) J. Kan. Entomol. Soc. 58:448-464.

Traynor, J. 2001. Blue orchard bees. Almond Grower Newsletter, Feb. 14, 2001. http://www.beesource.com/pov/traynor/agnewsfeb01.htm.

Unrath, C.R. 2000. Spray volume, canopy density, and other factors involved in thinner efficacy. HortScience 37:481-483.

Unrath, C.R., A.L. Kenworthy, and C.L. Bedford. 1969. The effect of Alar, succinamic acid 2,2-dimethyl hydrazide, on fruit maturation, quality and vegetative growth of sour cherries, Prunus cerasus L., cv. 'Montmorency'. J. Amer. Soc. Hort. Sci. 94:387-391.

Walker, W.V. and D.M. Glenn. 1988. Growth responses of young peach trees and changes in soil characteristics with sod and conventional planting systems J. Amer. Sci. Hort. Sci. 113:652-656.

Wang, H., M.G. Nair, G.M. Strasburg, Y.-C. Chang, A.M. Booren, J.I. Gray, and D.L. DeWitt. 1999. Antioxidant and anti-inflammatory activities of anthocyanins and their aglycones from tart cherries. J. Natural Prod. 62: 294-296.

Wang, Z. and D.R. Dilley. 1996. Ethanol vapor treatment. A new alternative approach to control superficial scald of apples. Proc. Mich. State Hort. Soc. 126:35-40.

Wang, Z. and D.R. Dilley. 2000. Initial low oxygen stress controls superficial scald of apples. Postharvest Biol. Technol. 18:201-213.

Weinbaum, S. A., R. S. Johnson and T.M. DeJong. 1992. Causes and consequences of overfertilizaton in orchards. HortTechnology 2(1):112-121.

Weinbaum, S.A., I. Klein, F.E. Broadbent, W.C. Micke, and T.T. Muraoka. 1984. Effects of time of nitrogen application and soil texture on the availability of isotopically labeled fertilizer nitrogen to reproductive and vegetative tissue of mature almond trees. J. Amer. Soc. Hort.Sci. 109:339-343.

Weinbaum, S.A., I. Klein, and T.T. Muraoka. 1987. Use of nitrogen isotopes and a light-textured soil to assess annual contributions of nitrogen from soil and storage pools in mature almond trees. J. Amer. Soc. Hort. Sci. 112:526-529.

Weinbaum, S.A., M.L. Mervin, and T.T. Muraoka. 1978. Seasonal variation in nitrate uptake efficiency and distribution of absorbed nitrogen in non-bearing prune trees. J. Amer. Soc. Hort. Sci. 103:516-519.

Williams, K.M. and M.A. Wright. 1991. "THIN-IT": An expert system for chemical thinning of apples. MCP14, Wash. State Univ. Coop. Ext. Serv.

Williams, M.W. 1980. Retention of fruit firmness and increase in vegetative growth and fruit set of apple with aminoethoxyvinylglycine. HortScience 15:76-77.

Williams, M.W. 1993. Sulfcarbamide: A blossom-thinning agent for apples. HortTechnology 3:322-324.

Williams, M.W. 1994. Factors influencing chemical thinning and update on new chemical thinning agents. Compact Fruit Tree 27:115-122.

Williams, M.W., S.A. Bound, J. Hughes, and S. Tustin. 1995. Endothall: A blossom thinner for apples. HortTechnology 5:257-259.

Wise, J.C., L.J. Gut, and R. Isaacs. 1999. Use of kaolin clay for Michigan fruit pest management. Proc. Mich. State Hort. Soc. 129:164-169.

Yahia, E.M. 1994. Apple flavor. Hort. Rev. 16:197-234.

Yoder, K.S., S.S. Miller, and R.E. Byers. 1999. Suppression of fire blight in apple shoots by prohexadione-calcium following experimental and natural inoculation. HortScience 34:1202-1204.

Zimmerman, R.H. and G.L. Steffens. 1996. Long-term evaluation of micropropagated apple trees. Vegetative growth, cropping and photosynthesis. Scientia Hort. 66:69-76. 